\title{
THE OCEANS 50TH ANNIVERSARY
}

\section{By D. James Baker}

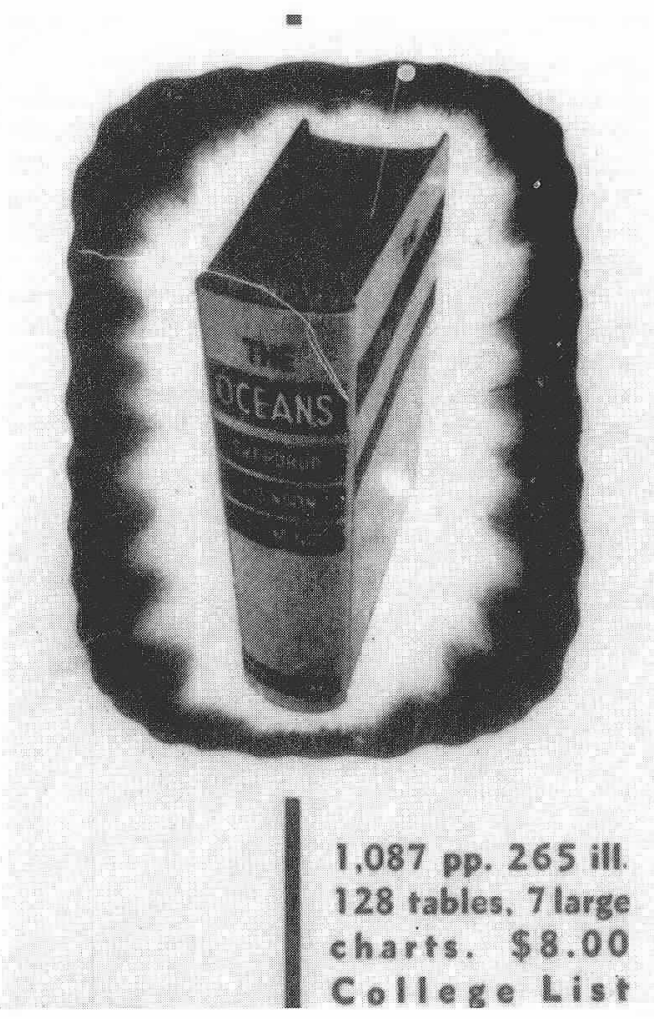

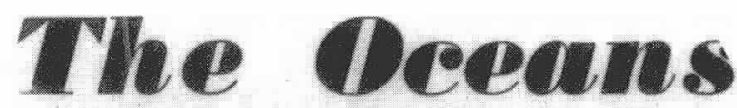

Their Physics, Chemistry and General Biology

H. U. SVERDRUP, Director and M. W. JOHNSON, R. H. FLEMINC, all of Seripps Institution of Oceanography, University of California

The only text, in any language, integrating ALL the sciences forming the broad subject of Oceanography - in ONE volume.

Marine Biology - covers one-third of the book, dealing especially with the sea as an environment for organisms.

Geographical section describes surface currents and temperatures.

Meteorological section gives facts, in addition to surface currents and temperatures, of the interaction between the atmosphere and the ocean.

Many chapters are devoted to Geology and Paleontology of the oceans as well.

One outstanding feature is the review of the modern technique for obtaining data from the sea, and in making hydrographic observations.
$T_{\text {he Oceans pulled }}$ together the field of oceanography ...
E ARLIER THIS YEAR, Carl Wunsch noted that it was exactly fifty years since The Oceans, subtitled "Their Physics, Chemistry, and General Biology" had been published by Prentice-Hall, Inc., and he proposed to me that Oceanography commission a review of that famous text. I thought that this was a superb idea, and found several colleagues who were enthusiastically ready to look at the book that has served so many oceanographers.

The Oceans pulled together the field of oceanography by being both a textbook and a documentation of the state of research: in detail for physics, chemistry, and biology, and briefly for

D.J. Baker, Joint Oceanographic Institutions, Suite 800 , 1755 Massachusetts Ave NW, Washington, DC 20036 USA. Editor Comment: We thank Deborah Day and the Scripps Institution of Oceanography at the University of California, San Diego, for contribution of photographs. Dean McManus supplied the photograph of Richard Fleming. marine geology. The Oceans defined oceanography in a way that would be difficult to do today. Now, there are many texts in the field, and we have encyclopedic multivolume sets in each of the disciplines of the field. But many of the same general questions raised in The Oceans still remain.

Each of the authors was asked to consider The Oceans in terms of how well it defined and affected a particular discipline at the time of publication, and how the text has stood the test of time. Not all the people asked were able to respond, but in the articles to follow, Bruce Warren, Sharon Smith, and Dean McManus have provided statements on the physics, marine biology, and geology. Walter Munk, who worked closely with Sverdrup at the time, has worked with Scripps archivist Deborah Day to discover some interesting material relating to the writing of the book itself.

Everyone has stories to tell about The Oceans: for me, I started in oceanography as a summer 
fellow at Scripps on an expedition in 1959 to the North Equatorial Current with John Knauss. John told me that if I wanted to be an oceanographer, I had to read The Oceans as a start. I didn't do it then, but when I finished my degree in 1962, I joined John for the first cruise of a set of Indian Ocean expeditions. I bought my copy at the Ed- ucational Book Centre, Ltd in Singapore; it still has the label. It's a well worn "Modern Asia" edition. I hand colored most of the water mass diagrams in Chapter 15, trying to understand how this all worked. Now my library is filled with oceanography texts and research journals, but I have a special place for The Oceans.

\title{
THE OCEAN “BIBLE": REMINISCENCES
}

\author{
By Walter H. Munk
}

$\mathbf{I}_{\mathrm{N}}$ occupied the southeast corner on the second floor of George Scripps Hall (now renovated through the efforts of Fred and Sally Spiess). William Ritter, the first Scripps Director, had lived on the second floor, and Harald's office had been Ritter's study and library. Every Tuesday afternoon Harald held "open door" for the affairs of the Institution. This left him with more time for his personal scientific work than most oceanographers at Scripps have today.

There is a nonfunctional fireplace at one end of the office and next to it a door leading to a small room where Harald's secretary, Ruth Ragan, held forth. She had spent 20 years in Japan at the YWCA before taking a job with Harald's predecessor, T. Wayland Vaughan. In addition to typing, proofing, and correcting the manuscript of The Oceans, she compiled the bibliographies. Miss Ragan also kept all the Scripps accounts. She once caught me using a Scripps envelope for my personal correspondence, and I received a stern note from HUS.

Harald's office had a small backdoor to the northeast leading into the hall opposite to a room that I occupied. It was summer 1940, and HUS was working on Chapter XV: "The Water Masses and Currents of the Oceans." Harald would appear at my door and say quietly: "come and listen." In the middle of his office there was a big wooden table piled high with books and papers in stacks corresponding to the major ocean basins. Harald would walk slowly around the table, pick

* He was "Dr. Sverdrup" for eight years before he invited me to call him Harald; all his notes were signed HUS.

W.H. Munk, Scripps Institution of Oceanography, University of California, San Diego, La Jolla, CA 92093, USA. up selected papers from the stacks, and speak out loud on what he thought were the essential features. He would go through this exercise many times following different guide lines. (It was at one of these sessions that he decided to organize the chapter around the Antarctic Ocean, looking at the Atlantic, Pacific and Indian Oceans as northward pointing fingers.) When he was ready he would call in Miss Ragan and dictate a section of the chapter without referring to any notes.

Occasionally he would have me read off numbers for him to plot. Today we have lost the excitement of wondering where the next point will fall. HUS would beam if a point confirmed a developing pattern, and scorn if it missed. Each point was taken seriously, and outliers were often rationalized. This is consistent with the motto expressed in the book's preface: “. . . we have, however, preferred definite statements to mere enumeration of uncorrelated observations and conflicting interpretations, believing the treatment selected would be more stimulating."

All of HUS writings were led by observational material. Mathematics was used as a concise $a$ posteriori discipline for organizing his thoughts, not as a means of deriving new insights. This was also true (but to a lesser extent) of Carl-Gustav Rossby who was visiting at the time. The procedure was in collision with Carl Eckart's a priori mathematical deductions and led to great frustrations on the part of Eckart.

Harald Sverdrup (and the rest of us) did not then understand the underlying concepts of continuous spectra as applied to geophysical processes. In a related vein, we did not understand the sampling requirements of continuous bandlimited processes, and the resulting aliasing of under-sampled fields. For 100 years every effort at
... organize the chapter around The

Antarctic Ocean,

looking at the Atlantic,

Pacific, and Indian

Oceans as northward

pointing fingers. 